\section{Planting Date Influences Fresh Pod Yield and Seed Chemical Compositions of Vegetable Soybean}

\author{
Yansheng Li
}

Key Laboratory of Mollisols Agroecology, Northeast Institute of Geography and Agroecology, Chinese Academy of Sciences, 138 Haping Road, Harbin, China

\author{
Ming Du \\ Rice Research Institute, Heilongjiang Academy of Land Reclamation \\ Sciences, 382 Jiaqing Street, Jiamusi, 154007, China
}

Qiuying Zhang', Guanghua Wang, and Jian Jin

Key Laboratory of Soybean Molecular Breeding, Northeast Institute of Geography and Agroecology, Chinese Academy of Sciences, 138 Haping Road, Harbin, 150081, China

\section{Stephen Herbert \\ Center for Agriculture, University of Massachusetts, Amherst, MA 01003}

Xiaobing Liu

Southern University Agricultural Research and Extension Center, Baton Rouge, LA 70813

Additional index words. vegetable soybean, edamame, sucrose, sowing date, food nutrition

\begin{abstract}
Planting date influences grain soybean yield and quality, but no information is available regarding the responses of seed chemical compositions to delayed planting date in vegetable soybean [Glycine max (L.) Merr.]. Three vegetable soybean cultivars, CAS No.1, Tai 292, and 121, were planted on 3 May, 15 May, 27 May, and 8 June in the field during the 2010 and 2011 growing seasons. The experiment was a randomized complete block design with three replications on a typical Mollisol (black soil). We found that late planting reduced fresh pod yield in all cultivars and years. The reduction in fresh pod yield to delayed planting was significantly correlated with the reduction in the number of two-seed pods per plant. Cultivars with strong capacity in retaining more two-seed pods may possess an advantage if planting is delayed. Planting after 15 May increased seed protein content by $4.1 \%$ to $7.5 \%$ and reduced oil content by $2.4 \%$ to $26.3 \%$ for different cultivars. The contents of free amino acid, sum of fructose and glucose, raffinose, and stachyose in seed were also increased by late planting. By contrast, late planting reduced the seed sucrose content ranging from $7.6 \%$ to $45.5 \%$ for the different cultivars. Planting on 3 May usually produced the greatest fresh pod yield and highest seed sucrose content. These results demonstrated that late planting after early May might have a negative impact on the eating quality of vegetable soybean.
\end{abstract}

Planting date is an important factor affecting soybean grain yield and grain quality. Early planting is recommended for soybean production in the northern and upper Midwest United States (De Bruin and Pedersen, 2008; Robinson et al., 2009). However, in some areas, early-planted soybean seed growth may be injured because of cool and wet soil conditions or late spring frost and thus result in reduced grain yield (Andales

\footnotetext{
Received for publication 25 Mar. 2014. Accepted for publication 18 Aug. 2014

This research was partially supported by Harbin Creative Talents Fund (2012RFXXN016), Natural Science Foundation of Heilongjiang Province of China (ZD201307), and the National Natural Science Foundation of China (31140066).

${ }^{1}$ To whom reprint requests should be addressed; e-mail zhangqiuying@iga.ac.cn.
}

et al., 2000; Meyer and Badaruddin, 2001). Egli and Cornelius (2009) reported the effect of planting date on soybean yield varied substantially from year to year in concert with variation in environmental conditions (principally rainfall amounts and distribution); however, yield was always reduced with delayed planting according to a summarizing planting date researches over the past 35 years. De Bruin and Pedersen (2008) found soybean yield declined $70 \mathrm{~kg} \cdot \mathrm{ha}^{-1} \cdot \mathrm{week}^{-1}$ when planting date was delayed between late April and early May in Iowa. Soybean yield was severely reduced when the planting date was delayed to late May or early June in the upper Midwest (Grau et al., 1994; Lueschen et al., 1992). Planting date affected the growth and development patterns of soybean and changed the content of protein, oil, carbohydrate, and other chemical components in seed $(\mathrm{Hu}$ and
Wiatrak, 2012; Kumar et al., 2006; Muhammad et al., 2009). Bellaloui et al. (2011) showed that early planting increased seed oil content by $16 \%$ compared with late planting with irrigation and reduced oil content was reported with delayed planting date (Kumar et al., 2006; Tremblay et al., 2006). The different temperature during seed filling of various planting dates was strongly correlated with oil content (Kane et al., 1997; Muhammad et al., 2009). Increased protein content across years and cultivars was reported with delayed planting (Kane et al., 1997; Muhammad et al., 2009). However, Tremblay et al. (2006) showed that no effect of delaying planting date from mid-May to mid-June on soybean protein content. All these studies mentioned were focused on the yield and quality of grain soybean. There is less information available for the effect of planting date on fresh pod yield, particularly for seed quality of vegetable soybean. The vegetable soybean is a larger seed soybean harvested at the R5 to R6 stage when seeds are immature and before pods turn yellow (Zhang et al., 2010). Vegetable soybean is very popular in East Asian countries. The literature history of Chinese eating maodou (vegetable soybean) can be traced to the Song dynasty (960 to 1279), recorded in a poem and an agronomy document. The vegetable soybean, edamame, became more acceptable in many countries in recent years because of its pleasant taste and high nutrient quality. Our objectives of this research were to determine the responses of fresh pod yield of vegetable soybean with emphasis on changes in seed chemical composition to planting date in northeast China.

\section{Materials and Methods}

Plant materials and treatment conditions. Field experiments were conducted at the agronomy farm of Northeast Institute of Geography and Agroecology, Chinese Academy of Sciences, Harbin, China (lat. $45^{\circ} 73^{\prime} \mathrm{N}$, long. $126^{\circ} 61^{\prime}$ E, altitude $128 \mathrm{~m}$ ) in the 2010 and 2011 growing seasons; daily maximum/ minimum temperature and precipitation of July, August, and September in 2010 and 2011 are shown in Figures 1 and 2. The experimental design was a randomized complete block design with three replications on a typical Mollisol (black soil). Four planting dates, 3 May, 15 May, 27 May, and 8 June, were established in the 2-year experiment. In 2010, one vegetable soybean cultivar, CAS No. 1, was planted, whereas in 2011, two additional vegetable soybean cultivars, Tai 292 and 121, were included. Each plot consisted of five rows with $0.65 \mathrm{~m}$ between rows. The row length was $5.0 \mathrm{~m}$. Seeds were planted with a grain drill at a depth of $3 \mathrm{~cm}$ and a rate of 280,000 seeds/ha. Based on earlier studies at this location, $50 \mathrm{~kg} \cdot \mathrm{ha}^{-1}$ carbamide [46\% nitrogen $(\mathrm{N})], 50 \mathrm{~kg} \cdot \mathrm{ha}^{-1}$ diammonium phosphate $(18 \% \quad \mathrm{~N}, 46 \%$ $\mathrm{P}_{2} \mathrm{O}_{5}$ ), and $150 \mathrm{~kg} \cdot \mathrm{ha}^{-1}$ of composite fertilizer $\left(18 \% \mathrm{~N}, 16 \% \mathrm{P}_{2} \mathrm{O}_{5}, 16 \% \mathrm{~K}_{2} \mathrm{O}\right)$ were applied before seeding (Zhang et al., 2010). Weeds were controlled by hand. Plants in the middle 


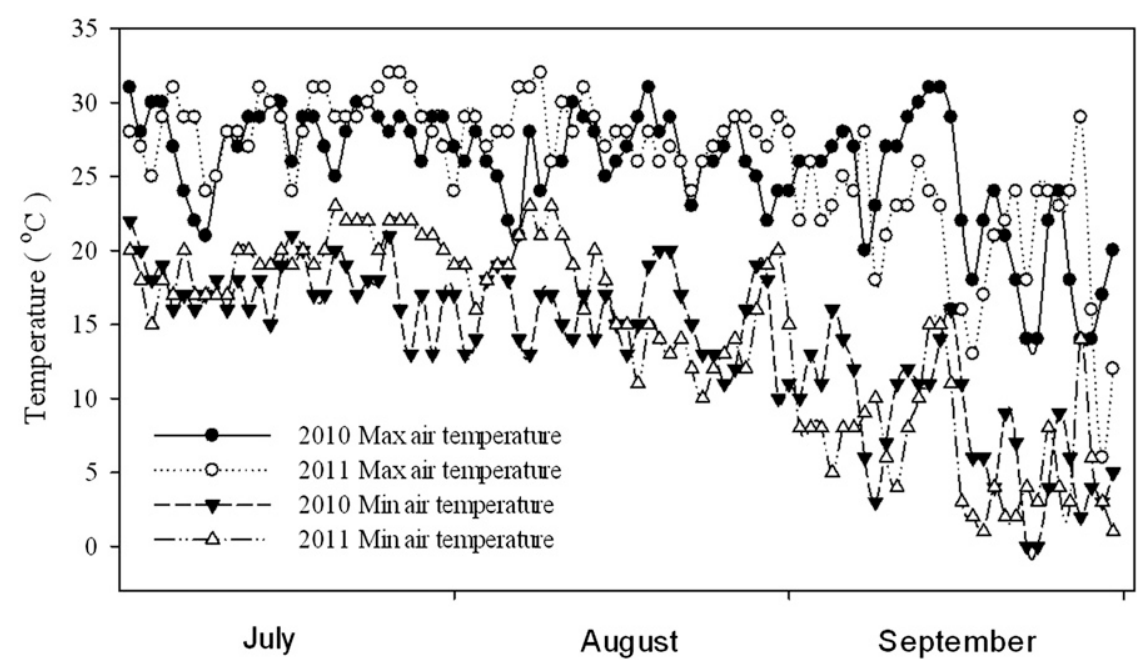

Fig. 1. Daily maximum and minimum temperature of July, August, and September i.e., R1 to R8 stage of soybean at Harbin in 2010 and 2011.

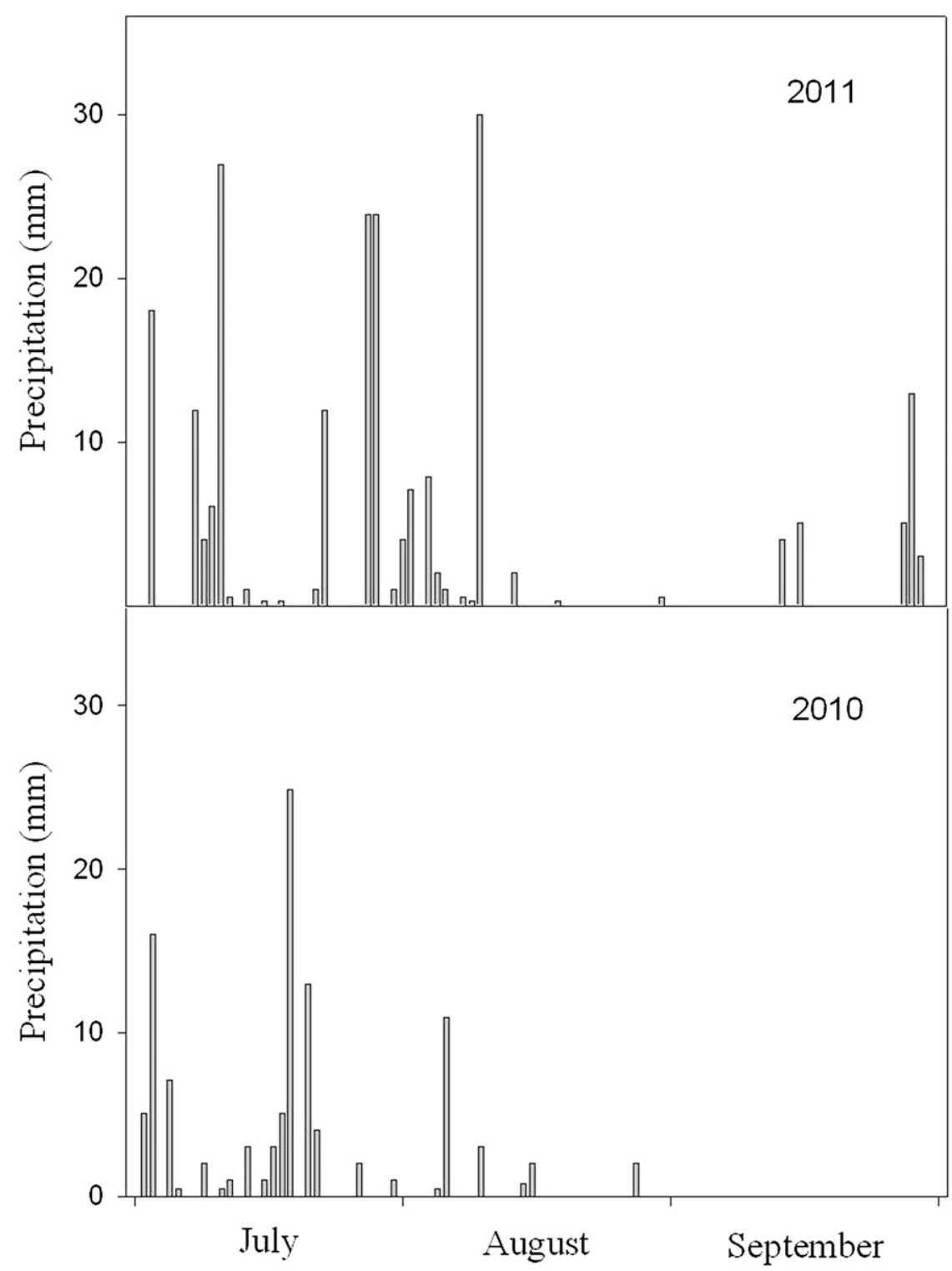

Fig. 2. Precipitation of July, August, and September i.e., R1 to R8 stage of soybean at Harbin in 2010 and 2011. two rows of each plot were harvested when the plants were at the R6 stage (Fehr et al., 1971). Fresh pods in $1.3 \mathrm{~m}^{2}$ from each plot were weighed for marketable yield. All plants were separated into one-seed, two-seed, and three-seed pods. Immediately after harvest, 150 fresh seeds were randomly selected from manually shelled pods. The fresh seed samples were weighed before being placed in a forcedair oven at $105^{\circ} \mathrm{C}$ for $30 \mathrm{~min}$ and then at $80^{\circ} \mathrm{C}$ for $72 \mathrm{~h}$. Ten grams of dried seeds were ground in a grinder (IKA-WERKE, Finland) to pass through a $147-\mu \mathrm{m}$ sieve for chemical composition analysis.

Measurement of protein, oil, and free amino acid content in seed. The crude protein of vegetable soybean was determined using the method of combustion $\mathrm{N}$ analysis by Elementar-Vario (Elementar Analysensysteme GmbH E-III, Germany). Total $\mathrm{N}$ was converted to the crude protein content using a conversion factor of 6.25 (Saldivar et al., 2011). The ninhydrin method was used to measure the total free amino acids. Oil content was determined using the Soxhlet extractor method where $0.5 \mathrm{~g}$ of dried sample was weighed and wrapped tightly using a weighted piece of filter paper and placed into Soxhlet apparatus (Shuniu, China) in a water bath maintained at $60{ }^{\circ} \mathrm{C}$. Then $200 \mathrm{~mL}$ of ethyl ether was added to the Soxhlet apparatus to extract oil. After a 48-h extraction period, the defatted sample was placed in a forced-air oven at $45{ }^{\circ} \mathrm{C}$ for $12 \mathrm{~h}$ and the weight was used to calculate the oil content by a difference method.

Analysis of sugars in seed. For content of sugars, $0.4 \mathrm{~g}$ of ground seed was extracted with $4 \mathrm{~mL} 80 \%$ ethanol in a $10-\mathrm{mL}$ centrifuge tube, which was then placed in an $80^{\circ} \mathrm{C}$ water bath for $40 \mathrm{~min}$ and then homogenized on a vortex for $10 \mathrm{~min}$. The mixture was then centrifuged at $4500 \mathrm{~g}$ for $3 \mathrm{~min}$ and the supernatant was removed to a new $10-\mathrm{mL}$ centrifuge tube and condensed to $1 \mathrm{~mL}$ using a rotary evaporator, after which it was filtered through a $0.2-\mu \mathrm{m}$ membrane for highperformance liquid chromatography (HPLC) analysis. A HPLC with Waters Refractive Index detection (HPLC-RID) was used for separation and measurement of each sugar. Samples were injected using a Waters autosampler. The sugars were separated on a BENSON polymeric ${ }^{\mathrm{TM}} 1000-0 \mathrm{BP}-100 \mathrm{Ca}++$ Carbohydrate Column $(250 \mathrm{~mm} \times 4 \mathrm{~mm}$ i.d. $)$ at a flow rate of $0.5 \mathrm{~mL} \cdot \mathrm{min}^{-1}$. The mobile phase was distilled water. The detection was accomplished using a RI2414 detector. Commercial sugars, including glucose, fructose, sucrose, raffinose, and stachyose, purchased from Sigma-Aldrich (St. Louis, MO), were used as external standards to identify and quantify each sugar based on their retention times and peak areas.

Data analysis. Data were presented as $\mathrm{mg} \cdot \mathrm{g}^{-1}$ of dry weight and were the averages of triplicate determinations. One-way analysis of variance tests were applied to confirm significant data for the same cultivar among different planting dates and different cultivars in the same planting date. The mean data 
were compared according to the Duncan's multiple range test at 5\% significant level. A partial-correlation model was used to describe the response of yield components to planting date. All data differences were analyzed at 5\% significant level across years. SPSS 13.0 software (SPSS Inc., Chicago, IL) was used to analyze for variance and mean comparison.

\section{Results}

Yield and yield components. Fresh pod yield of vegetable soybean decreased with delayed planting date (Table 1). Although a significant difference was observed between 2010 and 2011 for fresh pod yield for cv. CAS No. 1, the effect of delaying planting date on fresh pod yield was invariable. The highest fresh pod yield was consistently found in earlier planting dates in both years for all cultivars.

There was a large decrease in the number of two-seed pods per plant with delayed planting (Table 2). Further analysis demonstrated that only the decrease in the number of two-seed pods per plant was significantly correlated with fresh pod yield reduction (Table 3).

Seed protein, oil, and free amino acid content. Significant differences were observed among planting dates for seed protein content (Tables 4 to 6 ).

Planting date, year, cultivar, and the interaction of planting date $\times$ year had a significant impact on vegetable soybean seed oil content (Tables 4 and 5). Overall, a significant decrease in seed oil content was recorded after delaying planting date (Table 6).

The seed free amino acid content was significantly affected by planting dates and cultivar (Tables 4 to 6).

Seed sugar content. As a pair of isomeride, fructose and glucose were not discriminated by the HPLC-RID system, and it has been shown they had similar content and development trends during the seed filling stage (Saldivar et al., 2011). Therefore, we combined fructose and glucose for analysis. The sum of the two sugars was significantly affected by planting date, year, cultivar, the interaction of planting dates $\times$ year, and the interaction of planting dates $\times$ cultivar $(\mathrm{Ta}-$ bles 4 and 5). However, we found that late planting always increased the sum of the two sugars at the fresh edible stage (Table 7). Likewise, delayed planting increased the seed content of raffinose and stachyose, although the cultivars differed in their seed raffinose and stachyose contents (Table 7). The seed sucrose content was more than 15 times higher than all other sugars. However, unlike other sugars, delayed planting decreased the seed sucrose content (Table 7), and the seed sucrose content was unaffected by the interaction of planting dates $x$ year (Table 4). Although the cultivars differed in sucrose content, planting on 3 May always resulted in higher sucrose content than planting on later dates; the cultivar 121 exhibited a different response to delayed
Table 1. The response of fresh pod yield of vegetable soybean to planting date. ${ }^{\mathrm{z}}$

\begin{tabular}{|c|c|c|c|}
\hline $\mathrm{Yr}$ & Planting date & Cultivars & Fresh pod yield $\left(\mathrm{kg} \cdot \mathrm{ha}^{-1}\right)$ \\
\hline \multirow[t]{4}{*}{2010} & 3 May & CAS No. 1 & $10,980 \mathrm{a}^{*}$ \\
\hline & 15 May & CAS No. 1 & $8,352 b^{*}$ \\
\hline & 27 May & CAS No. 1 & $6,750 c^{*}$ \\
\hline & 8 June & CAS No. 1 & $6,588 \mathrm{c}^{*}$ \\
\hline \multirow[t]{12}{*}{2011} & 3 May & CAS No. 1 & $15,876 \mathrm{aA}$ \\
\hline & & Tai 292 & $16,866 \mathrm{aA}$ \\
\hline & & 121 & $13,644 \mathrm{aB}$ \\
\hline & 15 May & CAS No. 1 & $13,860 \mathrm{bA}$ \\
\hline & & Tai 292 & $13,158 \mathrm{bB}$ \\
\hline & & 121 & $13,014 \mathrm{aB}$ \\
\hline & 27 May & CAS No. 1 & $11,250 \mathrm{cA}$ \\
\hline & & Tai 292 & $11,682 \mathrm{bcA}$ \\
\hline & & 121 & $8,694 \mathrm{bB}$ \\
\hline & 8 June & CAS No. 1 & $10,638 \mathrm{cA}$ \\
\hline & & Tai 292 & $10,152 \mathrm{cAB}$ \\
\hline & & 121 & $9,594 \mathrm{bB}$ \\
\hline
\end{tabular}

${ }^{\mathrm{z}}$ For the same cultivar, means followed by the same lowercase letter in the same year are not significantly different among planting dates $(P=0.05)$. For the same planting date, means followed by the same uppercase letter in the same year are not significantly different among cultivars $(P=0.05)$.

*Significant difference between 2010 and 2011 at the same planting date $(P=0.05)$.

Table 2. The response of fresh pod number of 'CAS No. 1' to planting date in 2010 and $2011 .{ }^{\mathrm{z}}$

\begin{tabular}{lcccc}
\hline & & One-seed pod & Two-seed pod & Three-seed pod \\
\cline { 2 - 5 } Yr & Planting date & $8.3 \mathrm{a}$ & (pod number/plant) & \\
\hline 2010 & 3 May & $2.8 \mathrm{~b}$ & $20 \mathrm{a}$ & $4.2 \mathrm{~b}$ \\
& 15 May & $1.2 \mathrm{~b}$ & $14 \mathrm{~b}$ & $3.3 \mathrm{~b}$ \\
& 27 May & $3.4 \mathrm{~b}$ & $9.1 \mathrm{c}$ & $6.0 \mathrm{a}$ \\
2011 & 8 June & $7.0 \mathrm{a}$ & $9.2 \mathrm{c}$ & $4.0 \mathrm{~b}$ \\
& 3 May & $7.8 \mathrm{a}$ & $29 \mathrm{a}$ & $6.4 \mathrm{a}$ \\
& 15 May & $6.8 \mathrm{a}$ & $21 \mathrm{c}$ & $9.2 \mathrm{a}$ \\
& 27 May & $7.0 \mathrm{a}$ & $20 \mathrm{c}$ & $9.3 \mathrm{a}$ \\
& 8 June & & $6.0 \mathrm{a}$ \\
\hline
\end{tabular}

${ }^{\mathrm{z}}$ Means followed by the same letter in the same year are not significantly different among planting dates $(P=0.05)$.

Table 3. Analysis of correlation between fresh pod yield and different pod of 'CAS No. 1' after delayed planting.

\begin{tabular}{llccc}
\hline & & One-seed pod & Two-seed pod & Three-seed pod \\
\hline 2010 & $r$ & 0.402 & 0.616 & 0.003 \\
& Significance & 0.604 & 0.002 & 0.989 \\
& $r$ & -0.510 & 0.828 & -0.334 \\
& Significance & 0.850 & 0.000 & 0.206 \\
\hline
\end{tabular}

Table 4. Analysis of variance (F-value and level of significance) of the effect of year (2010, 2011), planting date, and their interactions on 'CAS No. 1' chemical composition.

\begin{tabular}{lccccccr}
\hline & Protein & Oil & FAA & F $+\mathrm{G}$ & Sucrose & Raffinose & Stachyose \\
\cline { 2 - 7 } & \multicolumn{7}{c}{$\left(\mathrm{mg} \cdot \mathrm{g}^{-1}\right)$} \\
\hline Year (Y) & $1.59 \mathrm{NS}$ & $383^{* * *}$ & $3.49 \mathrm{NS}$ & $47.0^{* * *}$ & $220^{* * *}$ & $0.03 \mathrm{NS}$ & $3.18 \mathrm{NS}$ \\
Planting date (P) & $119^{* * *}$ & $33.7^{* * *}$ & $39.4^{* *}$ & $26.6^{* * *}$ & $38.9^{* * *}$ & $94.5^{* * *}$ & $33.0^{* * *}$ \\
$\mathrm{P} \times \mathrm{Y}$ & $6.55^{*}$ & $9.08^{* *}$ & $0.35 \mathrm{NS}$ & $3.89^{*}$ & $1.10 \mathrm{NS}$ & $34.0^{* * *}$ & $2.01 \mathrm{NS}$ \\
\hline
\end{tabular}

$\mathrm{FAA}=$ free amino acid; $\mathrm{F}+\mathrm{G}=$ fructose + glucose

* Significant at the $0.05 P$ level.

** Significant at the $0.01 P$ level.

*** Significant at the $0.001 P$ level.

NS $=$ Nonsignificant at $P=0.05$.

Table 5. Analysis of variance (F-value and level of significance) of the effect of cultivars, i.e., CAS No. 1, Tai 292, and cv. 121, in 2011, planting date, and their interactions on chemical composition.

\begin{tabular}{lccccccr}
\hline & Protein & Oil & FAA & $\mathrm{F}+\mathrm{G}$ & Sucrose & Raffinose & Stachyose \\
\cline { 2 - 7 } & \multicolumn{7}{c}{$\left(\mathrm{mg} \cdot \mathrm{g}^{-1}\right)$} \\
\hline Cultivar (C) & $83.0^{* * *}$ & $4.91^{*}$ & $4.53^{*}$ & $12.5^{* * *}$ & $18.8^{* * *}$ & $15.7^{* * *}$ & $9.14^{* *}$ \\
Planting date (P) & $96.3^{* * *}$ & $3.83^{*}$ & $13.6^{* * *}$ & $22.9^{* * *}$ & $24.1^{* * *}$ & $31.1^{* * *}$ & $60.5^{* * *}$ \\
$\mathrm{P} \times \mathrm{C}$ & $4.26^{*}$ & $0.181 \mathrm{NS}$ & $1.15 \mathrm{NS}$ & $2.97^{*}$ & $2.46^{*}$ & $1.99 \mathrm{NS}$ & $2.45^{*}$ \\
\hline
\end{tabular}

FAA $=$ free amino acid; $\mathrm{F}+\mathrm{G}=$ fructose + glucose.

*Significant at the $0.05 P$ level.

**Significant at the $0.01 P$ level.

*** Significant at the $0.001 P$ level.

NS $=$ Nonsignificant at $P=0.05$. 
Table 6. The effect of planting date on protein, oil, and free amino acid content in vegetable soybean seed. ${ }^{z}$

\begin{tabular}{|c|c|c|c|c|c|c|}
\hline \multirow{2}{*}{ Chemical composition } & \multirow[b]{2}{*}{ Cultivars } & \multirow[b]{2}{*}{ Yr } & 3 May & 15 May & 27 May & 8 June \\
\hline & & & \multicolumn{4}{|c|}{$\left(\mathrm{mg} \cdot \mathrm{g}^{-1}\right)$} \\
\hline \multirow[t]{4}{*}{ Protein } & CAS No. 1 & 2010 & $401.9 \mathrm{c}$ & $405.1 \mathrm{c}$ & $418.5 \mathrm{~b}$ & $428.2 \mathrm{a}$ \\
\hline & CAS No. 1 & 2011 & $393.8 \mathrm{cB}$ & $408.0 \mathrm{bB}$ & $422.9 \mathrm{aB}$ & $423.2 \mathrm{aB}$ \\
\hline & Tai 292 & 2011 & 409.4 bA & $412.8 \mathrm{bB}$ & $435.1 \mathrm{aA}$ & $430.0 \mathrm{aA}$ \\
\hline & 121 & 2011 & $413.1 \mathrm{cA}$ & $432.8 \mathrm{bA}$ & $435.2 \mathrm{abA}$ & $441.6 \mathrm{aA}$ \\
\hline \multirow[t]{4}{*}{ Oil } & CAS No. 1 & 2010 & $169.5 \mathrm{a}$ & $147.8 \mathrm{~b}$ & $143.5 \mathrm{~b}$ & $125.0 \mathrm{c}$ \\
\hline & CAS No. 1 & 2011 & $192.9 \mathrm{aA}$ & $195.0 \mathrm{aA}$ & $187.4 \mathrm{aA}$ & $178.0 \mathrm{bA}$ \\
\hline & Tai 292 & 2011 & $198.3 \mathrm{aA}$ & $191.9 \mathrm{abAB}$ & $187.1 \mathrm{bA}$ & $171.8 \mathrm{cB}$ \\
\hline & 121 & 2011 & $180.1 \mathrm{aB}$ & $188.1 \mathrm{aB}$ & $175.8 \mathrm{bB}$ & $163.8 \mathrm{cC}$ \\
\hline \multirow[t]{4}{*}{ Free amino acid } & CAS No. 1 & 2010 & $7.03 \mathrm{c}$ & $7.31 \mathrm{c}$ & $9.05 \mathrm{~b}$ & $10.97 \mathrm{a}$ \\
\hline & CAS No. 1 & 2011 & $7.54 \mathrm{dA}$ & $8.28 \mathrm{cA}$ & $9.27 \mathrm{bA}$ & $11.33 \mathrm{aA}$ \\
\hline & Tai 292 & 2011 & $6.53 \mathrm{~dB}$ & $7.13 \mathrm{cB}$ & $8.88 \mathrm{bB}$ & $9.63 \mathrm{aB}$ \\
\hline & 121 & 2011 & $5.69 \mathrm{cC}$ & $7.15 \mathrm{bB}$ & $7.67 \mathrm{bC}$ & $8.31 \mathrm{aC}$ \\
\hline
\end{tabular}

${ }^{2}$ Within a row, means of the same chemical composition followed by the same lower letter are not significantly different among planting dates under same cultivar $(P=0.05)$. Within a column, means of the same chemical composition followed by the same uppercase letter in 2011 are not significantly different among three cultivars $(P=0.05)$.

Table 7. The effect of planting date on sugars in vegetable soybean seed. ${ }^{\mathrm{z}}$

\begin{tabular}{llccccc}
\hline & & 3 May & 15 May & 27 May & 8 June \\
\cline { 5 - 7 } Chemical composition & Cultivars & Yr & \multicolumn{4}{c}{$\left(\mathrm{mg}^{-1}\right)$} \\
\hline Fructose + glucose & CAS No. 1 & 2010 & $0.59 \mathrm{c}$ & $0.60 \mathrm{c}$ & $1.14 \mathrm{~b}$ & $1.32 \mathrm{a}$ \\
& CAS No. 1 & 2011 & $1.02 \mathrm{dA}$ & $1.18 \mathrm{cdC}$ & $1.81 \mathrm{aA}$ & $1.41 \mathrm{bcC}$ \\
& Tai 292 & 2011 & $0.92 \mathrm{cC}$ & $1.25 \mathrm{bB}$ & $1.57 \mathrm{aB}$ & $1.63 \mathrm{aB}$ \\
Sucrose & 121 & 2011 & $0.98 \mathrm{cB}$ & $1.65 \mathrm{bA}$ & $1.43 \mathrm{bC}$ & $2.09 \mathrm{aA}$ \\
& CAS No. 1 & 2010 & $22.4 \mathrm{a}$ & $18.7 \mathrm{~b}$ & $15.6 \mathrm{c}$ & $16.8 \mathrm{c}$ \\
& CAS No. 1 & 2011 & $30.1 \mathrm{aB}$ & $27.8 \mathrm{bB}$ & $22.0 \mathrm{cA}$ & $24.4 \mathrm{cA}$ \\
& Tai 292 & 2011 & $28.8 \mathrm{aC}$ & $24.3 \mathrm{bC}$ & $20.7 \mathrm{cB}$ & $21.5 \mathrm{cB}$ \\
Raffinose & 121 & 2011 & $39.4 \mathrm{aA}$ & $33.0 \mathrm{bA}$ & $21.5 \mathrm{~dB}$ & $24.0 \mathrm{cA}$ \\
& CAS No. 1 & 2010 & $1.03 \mathrm{c}$ & $0.97 \mathrm{c}$ & $1.47 \mathrm{~b}$ & $1.66 \mathrm{a}$ \\
& CAS No. 1 & 2011 & $0.37 \mathrm{cC}$ & $0.50 \mathrm{cC}$ & $2.58 \mathrm{aA}$ & $1.63 \mathrm{bB}$ \\
Stachyose & Tai 292 & 2011 & $1.31 \mathrm{cA}$ & $1.77 \mathrm{bA}$ & $2.11 \mathrm{aB}$ & $1.97 \mathrm{aA}$ \\
& 121 & 2011 & $1.20 \mathrm{cB}$ & $1.38 \mathrm{cB}$ & $2.54 \mathrm{aA}$ & $1.92 \mathrm{bA}$ \\
& CAS No. 1 & 2010 & $1.43 \mathrm{c}$ & $2.03 \mathrm{~b}$ & $1.98 \mathrm{~b}$ & $2.25 \mathrm{a}$ \\
& CAS No. 1 & 2011 & $1.56 \mathrm{dA}$ & $1.91 \mathrm{cA}$ & $2.11 \mathrm{bA}$ & $2.58 \mathrm{aA}$ \\
& Tai 292 & 2011 & $1.30 \mathrm{cC}$ & $1.80 \mathrm{bB}$ & $1.92 \mathrm{bB}$ & $2.41 \mathrm{aB}$ \\
& 121 & 2011 & $1.45 \mathrm{cB}$ & $1.85 \mathrm{abAB}$ & $1.78 \mathrm{bC}$ & $1.97 \mathrm{aC}$ \\
\hline
\end{tabular}

${ }^{\mathrm{z}}$ Within a row, means of the same chemical composition followed by the same lower letter are not significantly different among planting dates $(P=0.05)$. Within a column, means of the same chemical composition followed by the same uppercase letter in 2011 are not significantly different among three cultivars $(P=0.05)$.

planting date than the other two cultivars (Table 7).

\section{Discussion}

Changes in the planting dates are known to influence the yield of soybean. The results from this study support previous conclusions in grain soybean that earlier0planted soybean produced more grain yields (Egli and Cornelius, 2009; Oplinger and Philbrook, 1992). The reduction in fresh pod yield of vegetable soybean induced by delayed planting date might be in part attributable to the shortened duration of seed filling in later planting dates (Weaver et al., 1991). Shorter duration of vegetative and reproductive stages could result in yield reduction because of decreased pod number and seed number per unit area (Egli and Bruening, 2000; Chen and Wiatrak, 2010). Zhang et al. (2010) proposed that the decline in marketable yield of vegetable soybean by 34 to $55 \mathrm{~kg} \cdot \mathrm{ha}^{-1} \cdot \mathrm{d}^{-1}$ with delayed sowing date was mainly related to the decrease in two-seed and three-seed pods. Results of our study further revealed that the number of two-seed pods might be the major to $28^{\circ} \mathrm{C}$ ) was exposed to higher temperature than late-planted soybean $\left(16\right.$ to $\left.26{ }^{\circ} \mathrm{C}\right)$ during the R5 to R6 stage. This might be the reason for the higher seed protein content to the later-planted vegetable soybean. Because protein and oil in mature soybean seed are negatively correlated (Watanabe and Nagasawa, 1990), the response of oil content of vegetable soybean would be expected to be opposite the response of protein, i.e., it would be reduced by delayed planting as found in this study. The exposure to lower temperature during the R5 to R6 stage with late planting in this study might also be the reason for the reduction of oil content in the vegetable soybean. However, the temperature during the R5 to R6 stage was different between 2010 and 2011 (Fig. 1). This may explain the interaction effect of planting date $\times$ year on seed oil content of 'CAS No. 1' (Table 4). In mature soybean, seed oil content was always decreased in a high-temperature environment (Rotundo and Westgate, 2009). These findings on delayed planting date in changing the quality trait of vegetable soybean could be meaningful because a high protein with relatively low oil content is an important quality trait for healthy food.

Free amino acid of soybean seed not only confers health benefits to humans, but also affects food taste (Bandegan et al., 2011). In the present study, the response of free amino acid content of seed to planting date was similar to seed protein content. The positive correlation $(P<0.05)$ between free amino acid of soybean seed and seed protein content has been reported (Hernandez-Sebastia et al., 2005), and free amino acid level in vegetable soybean seed was controlled by the balance between protein synthesis activities and amino acid supplied from different parts of the plant. Fresh seed free amino acid concentration was different among vegetable soybean cultivars, whereas crop conditions and ripe stage also affected the accumulation of free amino acid (Song et al., 2013). Thus, the changed environment during the seed filling stage caused by delayed planting date may influence the fresh seed free amino acid concentration significantly.

The accumulation of sugars is affected by the temperature during the seed filling stage and cultivars differ in sugar accumulation. Delayed planting date in the present studies did not have a similar effect on cultivars. Table 5 shows the planting date $\times$ cultivar interaction was significant for fructose + glucose, sucrose, and stachyose. Table 4 shows the planting date $\times$ year interaction with 'CAS No. 1 ' was significant only for fructose + glucose and raffinose. The present study confirmed that sucrose is the predominant sugar in the seed of vegetable soybean (Mebrahtu and Devine, 2009) and that delayed planting reduced sucrose content. Sucrose is a major product of photosynthesis and the main substrate for sink metabolism. Shorter post-flowering photoperiod by delayed planting might be responsible for the reduction in sucrose content because sucrose is transported from synthesizing (source) organs to sink organs where it is stored 
(Lemoine, 2000), and any reduced type of source organs would influence sucrose accumulation. Furthermore, sucrose is a signal molecule for regulating the source-sink relationship. The weaker sink strength after delayed planting date may feed back in reducing the photosynthetic ability and thus decrease sucrose supply (Chiou and Bush, 1998).

Although the most abundant sugar was sucrose, and fructose and glucose are not considered important in mature seed of grain soybean, Santana et al. (2012) reported these sugars may be associated with the unique and distinct flavor of the vegetable soybean seed. Fructose and glucose levels were found to be higher in vegetable-type soybean than that in grain soybean (Silva et al., 2009). Although delayed planting increased the sum of fructose and glucose in this study, the maximum sum of the two sugars was only $2.09 \mathrm{mg} \cdot \mathrm{g}^{-1}$ and thus its influence on flavor of vegetable soybean is likely quite limited. Raffinose and stachyose are undesirable constituents of food because they result in flatulence and abdominal discomfort for humans and animals (Kumar et al., 2012). The present study found that the content of raffinose and stachyose in vegetable soybean seed was between 0.37 to $2.58 \mathrm{mg} \cdot \mathrm{g}^{-1}$ and 1.30 to $2.58 \mathrm{mg} \cdot \mathrm{g}^{-1}$, respectively, which was much lower than that in mature grain soybean seed ( 10 to $20 \mathrm{mg} \cdot \mathrm{g}^{-1}$ and 50 to $60 \mathrm{mg} \cdot \mathrm{g}^{-1}$, respectively) (Francis et al., 2001). Therefore, the relative increase in raffinose and stachyose with delayed planting would not influence the characteristics of vegetable soybean as a healthy food. However, because sucrose is intensely associated with the eating quality of vegetable soybean and the cultivar with higher sucrose level is preferred in the market, the potential negative impact on the eating quality of vegetable soybean induced by delayed planting date deserves more attention.

\section{Literature Cited}

Andales, A.A., W.D. Batchelor, and C.E. Anderson. 2000. Modification of a soybean model to improve soil temperature and emergence date prediction. T. Asae 43:121-129.

Bandegan, A., A. Golian, E. Kiarie, R.L. Payne, G.H. Crow, W. Guenter, and C.M. Nyachoti. 2011. Standardized ileal amino acid digestibility in wheat, barley, pea and flaxseed for broiler chickens. Can. J. Anim. Sci. 91:103-111.

Bellaloui, N., K.N. Reddy, A.M. Gillen, D.K. Fisher, and A. Mengistu. 2011. Influence of planting date on seed protein, oil, sugars, minerals, and nitrogen metabolism in soybean under irrigated and non-irrigated environments. Amer. J. Plant Sci. 02:702-715.

Chen, G.H. and P. Wiatrak. 2010. Soybean development and yield are influenced by planting date and environmental conditions in the southeastern coastal plain, United States. Agron. J. 102:17311737.

Chiou, T.J. and D.R. Bush. 1998. Sucrose is a signal molecule in assimilate partitioning. Proc. Natl. Acad. Sci. USA 95:4784-4788.

Dardanelli, J.L., M. Balzarini, M.J. Martinez, M. Cuniberti, S. Resnik, S.E. Ramunda, R. Herrero, and H. Baigorri. 2006. Soybean maturity groups, environments, and their interaction define mega-environments for seed composition in Argentina. Crop Sci. 46:1939-1947.

De Bruin, J.L. and P. Pedersen. 2008. Soybean seed yield response to planting date and seeding rate in the upper Midwest. Agron. J. 100:696703.

Egli, D.B. and W.P. Bruening. 2000. Potential of early-maturing soybean cultivars in late plantings. Agron. J. 92:532-537.

Egli, D.B. and P.L. Cornelius. 2009. A regional analysis of the response of soybean yield to planting date. Agron. J. 101:330-335.

Fehr, W.R., C.E. Caviness, D.T. Burmood, and J.S Penningt. 1971. Stage of development descriptions for soybeans, Glycine Max (L). Merrill. Crop Sci. 11:929-931.

Francis, G., H.P.S. Makkar, and K. Becker. 2001 Antinutritional factors present in plant-derived alternate fish feed ingredients and their effects in fish. Aquaculture 199:197-227.

Grau, C.R., E.S. Oplinger, E.A. Adee, E.A. Hinkens, and M.J. Martinka. 1994. Planting date and row width effect on severity of brown stem rot and soybean productivity. J. Prod. Agr. 7:347351.

Hernandez-Sebastia, C., F. Marsolais, C. Saravitz, D. Israel, R.E. Dewey, and S.C. Huber. 2005. Free amino acid profiles suggest a possible role for asparagine in the control of storage-product accumulation in developing seeds of lowand high-protein soybean lines. J. Expt. Bot. 56:1951-1963.

Hu, M.X. and P. Wiatrak. 2012. Effect of planting date on soybean growth, yield, and grain quality. Agron. J. 104:785-790.

Kane, M.V., C.C. Steele, L.J. Grabau, C.T. MacKown, and D.F. Hildebrand. 1997. Early-maturing soybean cropping system. III: Protein and oil contents and oil composition. Agron. J. 89:464-469.

Kumar, V., G.S. Chauhan, A. Rani, M. Raghvanshi, and R. Jatav. 2012. Effect of boiling treatments on biochemical constituents of vegetable-type soybean. J. Food Process Pres. 36:393-400

Kumar, V., A. Rani, V. Pandey, P. Mande, and G.S. Chauhan. 2006. Compositional traits of soybean seeds as influenced by planting date in India. Exp. Agric. 42:19-28.

Lemoine, R. 2000. Sucrose transporters in plants: Update on function and structure. BbaBiomembranes 1465:246-262.

Lueschen, W.E., J.H. Ford, S.D. Evans, B.K. Kanne, T.R. Hoverstad, G.W. Randall, J.H. Orf, and D.R. Hicks. 1992. Tillage, row spacing, and planting date effects on soybean following corn or wheat. J. Prod. Agr. 5:254-260.
Mebrahtu, T. and T.E. Devine. 2009. Diallel analysis of sugar composition of 10 vegetable soybean lines. Plant Breed. 128:249-252.

Meyer, D.W. and M. Badaruddin. 2001. Frost tolerance of ten seedling legume species at four growth stages. Crop Sci. 41:1838-1842.

Mishra, V. and K.A. Cherkauer. 2010. Retrospective droughts in the crop growing season: Implications to corn and soybean yield in the Midwestern United States. Agr. For. Meteorol. 150:1030-1045.

Muhammad, A., S.K. Khalil, K.B. Marwat, A.Z. Khan, I.H. Khalil, J. Amanullah, and S. Arifullah. 2009. Nutritional quality and production of soybean land races and improved varieties as affected by planting dates. Pak. J. Bot. 41:683689.

Oplinger, E.S. and B.D. Philbrook. 1992. Soybean planting date, row width, and seeding rate response in three tillage systems. J. Prod. Agr. 5:94-99.

Robinson, A.P., S.P. Conley, J.J. Volenec, and J.B. Santini. 2009. Analysis of high yielding, earlyplanted soybean in Indiana. Agron. J. 101:131139.

Rotundo, J.L. and M.E. Westgate. 2009. Metaanalysis of environmental effects on soybean seed composition. Field Crops Res. 110:147-156.

Saldivar, X., Y.J. Wang, P. Chen, and A. Hou. 2011. Changes in chemical composition during soybean seed development. Food Chem. 124:1369-1375

Santana, A.C., M.C. Carrao-Panizzi, J.M.G. Mandarino, R.S. Leite, J.B. Silva, and E.I. Ida. 2012. Effect of harvest at different times of day on the physical and chemical characteristics of vegetable-type soybean. Ciencia Tecnol. Alime. 32:351-356.

Silva, J.B., M.C. Carrao-Panizzi, and S.H. Prudencio. 2009. Chemical and physical composition of grain-type and food-type soybean for food processing. Pesquisa Agropecu. Bras. 44:777784.

Song, J.F., C.Q. Liu, D.J. Li, and Z.X. Gu. 2013. Evaluation of sugar, free amino acid, and organic acid compositions of different varieties of vegetable soybean [Glycine max (L.) Merr]. Ind. Crops Prod. 50:743-749.

Tremblay, G.J., J.M. Beausoleil, P. Filion, and M. Saulnier. 2006. Response of three soybean cultivars to seeding date. Can. J. Plant Sci. 86:1071-1078.

Watanabe, I. and T. Nagasawa. 1990. Appearance and chemical composition of soybean seeds in germplasm collection of Japan. 2. Correlation among protein, lipid and carbohydrate percentage. Jpn. J. Crop. Sci. 59:661-666.

Weaver, D.B., R.L. Akridge, and C.A. Thomas. 1991. Growth habit, planting date, and rowspacing effects on late-planted soybean. Crop Sci. 31:805-810.

Zhang, Q.Y., Q.L. Gao, S.J. Herbert, Y.S. Li, and A.M. Hashemi. 2010. Influence of sowing date on phenological stages, seed growth and marketable yield of four vegetable soybean cultivars in North-eastern USA. African J. Agr. Res. 5:2556-2562. 